\title{
Effects of Ground and Unground Rice Straw on the Yield and Proximate Composition of Groundnut (Arachis hypogeae L.)
}

\author{
Abdul'Aziz AYINLA*, Bolaji U. OLAYINKA, Emmanuel O. ETEJERE \\ University of Ilorin, Faculty of Life Science, Department of Plant Biology, PMB 1515, Ilorin, \\ Nigeria; ayinlaabdulaziz@gmail.com (*correspondingauthor);umarbolaji@yahoo.com; eotejere@yahoo.com
}

\begin{abstract}
A field experiment was carried out to evaluate the influence of ground and unground rice straw application as organic manure on the yield and proximate composition of groundnut seeds, at the University of Ilorin teaching and research farm. The field layout was a split plot Complete Randomized Block Design with four replications. The ground and unground rice straw were in the main plot and different application rates of the rice straw $(0 ; 1,250 ; 2,500 ; 3,750$ and $5,000 \mathrm{~kg} / \mathrm{ha})$ were in the subplots. The results revealed that ground and unground rice straws at 1,250 and $2,500 \mathrm{~kg} /$ ha application rates significantly increased $(\mathrm{p}<0.05)$ yield attributes such as pods' number with a range of 48.33-74.33 pod weight (23.95-42.70), number of seeds (45.67-77.33), seeds' weight (13.55-25.56 g) and hundred seed weight $(34.34-38.05 \mathrm{~g})$ as well as some aspect of proximate composition such as ash content, crude protein and crude fats which ranged between $2.71-2.79 \%, 31.47-31.56 \%$ and $46.61-47.13 \%$ respectively, in order of their mention. The forgoing study revealed that ground and unground rice straw applied at the rate of 1,250 and $2,500 \mathrm{~kg} / \mathrm{ha}$ can serve as an alternative for soil nutrient amendment in groundnut as it ensured a reasonable yield that is able to meet the nutritional needs of man and livestock.
\end{abstract}

Keywords: application rates, groundnut, proximate composition, rice straw, yield attribute

\section{Introduction}

Groundnut (Arachis hypogaea L.) is one of the world's most popular oil seed crop, cultivated in the tropical and subtropical part of the world (Olayinka and Etejere, 2013). It contains about 45 to $50 \%$ oil, 25 to $30 \%$ protein, $20 \%$ carbohydrate, $5 \%$ each of fibre and ash, all which makes it a substantial contribution to human nutrition (Fageria et al., 2010). It is also a rich source of phosphor, potassium, calcium and magnesium, as well as vitamin E, K and B (Savage and Keenan, 1994). Achou et al. (2005) reported groundnut seeds consumption as a supplement for the staple carbohydrate food where protein food of animal origin is unaffordable.

The high nutrient demand of this crop from the soil has limited its yield potentials. Inorganic fertilizer application have been considered as soil amendment to help increase groundnut yield, especially in commercial production; however, its prolong use have been associated with soil degradation, nutrient imbalance and soil acidity (Obi and Ebo, 1995; Basel and Sami, 2014). Recently, a better soil-friendly amendment practice is gaining attention from researchers, as several studies have been conducted on soil amendment from organic sources ranging from poultry manure, farm yard manure to vermicompost amongst others, all of which have been reported to enhance yield in groundnut also (Veluchamy et al., 2010; Mathivanan et al., 2013).
The global production of rice straw amounts to approximately 731 million tons annually (Binod et al., 2010). Only 20\% of the declared amount were used for purposes such as ethanol, paper and fertilizer production, as well as fodders for animals consumption (El-Gammal et al., 2001), while the remaining $80 \%$ is left on the field for burning or decomposition. This contributes to atmospheric pollution and soil nutrient loss.

In order to increase the rice straw percentage in use and minimize the usual burning practice, the present research was conducted to evaluate the effect of ground and unground rice straw on yield and proximate composition of harvested groundnut seeds when applied to the soil as organic manure.

\section{Materials and Methods}

\section{Experimentalsite}

The experiment was conducted at the University of Ilorin Botanical Garden, Ilorin. The experimental site was situated between longitude $4^{\circ} 38.920^{1} \mathrm{E}$ and $4^{\circ} 39.971^{1} \mathrm{E}$ and latitude $8^{\circ}$ $27.810^{1} \mathrm{~N}$ and $8^{\circ} 28.230^{1} \mathrm{~N}$. The soil was sandy-loam with a $\mathrm{pH}$ of 7.5.

\section{Experimental desion and treatment details}

The experimental layout was a split plot design with a gross plot dimension of $24.50 \times 9.50 \mathrm{~m}$. The net-plot was $2.0 \times 2.0 \mathrm{~m}$, consisting of four ridges with inter-row spacing of $0.15 \mathrm{~m}$. The net-plot arrangement followed a complete randomized design 
with four replications, each of ground and unground rice straw at different application rates: $T_{1}=1,250 \mathrm{~kg} / \mathrm{ha} ; T_{2}=2,500 \mathrm{~kg} / \mathrm{ha}$; $\mathrm{T}_{3}=3,750 \mathrm{~kg} / \mathrm{ha} ; \mathrm{T}_{4}=5,000 \mathrm{~kg} / \mathrm{ha}$ and $\mathrm{T}_{0}=0 \mathrm{~kg} / \mathrm{ha}$.

\section{Mineral analysis of rice straw}

The rice straw sample used was analysed for both macro and micro nutrients. Total nitrogen was determined by microKjedhal method as adopted by Bremner (1996). Total phosphorus was determined by the ammonium molybdate /vanadate yellow colour method following ternary acidperchloric-nitric-sulphuric acid wet digestion (Anderson and Ingram, 1994), total boron by azomethane-hydrogen method following Ternary acid digestion (Jones, 1991). Total cations: calcium (Ca), magnesium $(\mathrm{Mg})$, copper $(\mathrm{Cu})$, iron $(\mathrm{Fe})$, manganese $(\mathrm{Mn})$ and zinc $(\mathrm{Zn})$ were determined by atomic spectrophotometer. Elements such as sodium $(\mathrm{Na})$ and potassium $(\mathrm{K})$ were analysed using flame photometry following a wet digestion with perchloric-sulphuric ternary acid (Anderson and Ingram, 1994). Sulphur was determined by turbidometry, organic matter and ash content using the method described by Okalebo et al. (2002), while organic carbon was determined using Walkley-Black method as detailed by Nelson and Sommer (1982).

\section{Fieldplanting}

The field was mechanically ploughed to loosen the soil after which ground and unground rice straw, at different application rates, were incorporated into the soil at a depth of $0.1 \mathrm{~m}$. Thereafter, ridges were made by the use of hoe. The plots were watered to saturation point daily for a period of two weeks to enable rapid decay of the rice straw. Viable 'MK373' groundnut seeds, collected from College of Agriculture Mokwa, were sown at a depth of $0.03 \mathrm{~m}$ and a spacing of $0.1 \mathrm{~m}$ following a pretreatment of the seeds with $500 \mathrm{mg} / \mathrm{kg}$ dress Force $42 \mathrm{WS}$ (20\% imidacloprid, 20\% metalaxyl $-\mathrm{M}$ and $2 \%$ tebuconazole). Hand weeding was done to remove weeds at an interval of two weeks throughout the period of the experiment. Since the experiment was carried out during the dry season 2,500 L of water were used to irrigate the plots to saturation point at interval of forty eight hours ( 48 hours) throughout the period of the investigation.

\section{Yield attributes}

Number of fully developed pods was manually counted from each of the representative plants and the average was obtained as the number of matured pods per plant. The pod weight was also obtained by the use of a weighing balance after air drying to $12 \%$ moisture level. The average was then recorded as the mean pod weight; thereafter, the shells were removed and the seeds were manually counted and recorded; they were weighed and the mean was recorded as average seeds' weight, whereas 100-seeds weight was also determined.

\section{Proximate analysis of the groundnut seeds}

Proximate composition of air dried groundnut seeds before planting and at harvest was determined according to the methods of Official Analytical Chemists (AOAC, 2000). Moisture content was determined by drying $2 \mathrm{~g}$ of air dried seeds in an oven at $105^{\circ} \mathrm{C}$ for 5 hours. Ash content was determined by incinerating $2 \mathrm{~g}$ of sample in a muffle furnace at $600^{\circ} \mathrm{C}$ for 3 hours, until a greyish ash was formed. Crude fibre was determined by extracting $2.0 \mathrm{~g}$ of the ground sample with hexane, in a thimble, for 6 hours, to free the fat sample.
Thereafter, the sample was hydrolysed using $1.25 \%$ tetraoxosulphate (vi) acid to remove digestible nutrient in the fat; it was then filtered and the resulting filtrate was incinerated in a muffle furnace at $600^{\circ} \mathrm{C}$ for $30 \mathrm{~min}$, cooled in a desiccator and weighed. Crude protein was calculated by multiplying factor $(\% \mathrm{~N} \times 6.25)$ following a \% nitrogen determination by the Kjedhal method using $2 \mathrm{~g}$ of ground seed samples. Crude fat was determined by manually extracting $2 \mathrm{~g}$ of samples with $150 \mathrm{ml}$ petroleum ether in a soxhlet extractor at a boiling point of 60-80 ${ }^{\circ} \mathrm{C}$. Total carbohydrate was determined by subtracting the sum of ash, crude protein, crude fibre, crude fat and moisture from one hundred seeds.

\section{Data analysis}

Data were analysed using Analysis of Variance (F test) with Statistical Package for Social Science (SPSS) software version 16.0. Significant test results followed the Duncan multiple range Test (DMRT) at 5\% level of probability for identification of important contrasts.

\section{Results and Discussion}

\section{Mineral analysis of rice straw before planting}

The proximate composition of rice straw before its application as manure is shown in Table 1 . Rice straw contained moderate organic carbon $(1.08 \%)$, high organic matter $(75 \%)$, was very rich in phosphorus $(1,170.00 \mathrm{mg}$ $\left.\mathrm{kg}^{-1}\right)$, rich in calcium, magnesium and sulphur (470.30, 320.0 and $390.40 \mathrm{mg} \mathrm{kg}^{-1}$ respectively), also had a solid content of iron and zinc (500.25 and $330.50 \mathrm{mg} \mathrm{kg}^{-1}$ ), while other mineral elements such as boron, potassium, manganese, copper and sodium had relatively low values $\left(4.0,1.5,115 \mathrm{mg} \mathrm{kg}^{-1}\right)$ respectively. The results showed that rice straw was rich in organic matter and other mineral nutrient necessary for plant growth. Similar results were obtained by Olayinka and Etejere (2013).

\section{Yield attributes of groundnut}

The effects of ground and unground rice straw at different application rate on yield attributes are shown in Table 2. Ground and unground rice straw at $1,250 \mathrm{~kg} / \mathrm{ha}$ application rates significantly increased $(p<0.05)$ the number of pods and pod weight when compared to all other application rates. No significant effect was recorded for pod length at all application rates. Number of seeds per plant, seeds' weight and 100-seeds weight were

Table 1. Mineral analysis of rice straw

\begin{tabular}{lc}
\hline Mineral/Component & Content (value) \\
\hline Organic carbon & $1.87 \%$ \\
Organic matter & $3.22 \%$ \\
Sulphur & $390.40 \mathrm{mg} / \mathrm{kg}$ \\
Phosphorus & $1170.00 \mathrm{mg} / \mathrm{kg}$ \\
Iron & $500.25 \mathrm{mg} / \mathrm{kg}$ \\
Nitrogen & $1.05 \%$ \\
Potassium & $1.50 \%$ \\
Calcium & $470.30 \mathrm{mg} / \mathrm{kg}$ \\
Magnesium & $320.00 \mathrm{mg} / \mathrm{kg}$ \\
Copper & $19.30 \mathrm{mg} / \mathrm{kg}$ \\
Zinc & $330.50 \mathrm{mg} / \mathrm{kg}$ \\
Manganese & $115.60 \mathrm{mg} / \mathrm{kg}$ \\
Boron & $4.00 \mathrm{mg} / \mathrm{kg}$ \\
\hline
\end{tabular}


178

significantly the highest in ground and unground rice straw applied at the rate of $1,250 \mathrm{~kg} / \mathrm{ha}$ and $2,500 \mathrm{~kg} / \mathrm{ha}$ respectively, compared to other application rate; curiously, 3,750 $\mathrm{kg} / \mathrm{ha}$ application rates had no significant effect on seeds' weight and 100-seeds weight.

The increased number of pods per plant and pod weight per plant could be traced to the large amount of calcium and potassium resulting from accelerated mineralization of the rice straw; Jana et al. (1990) has reported increased number of pods per plant, pod weight, pod yield and oil yield in groundnut plant upon increased potassium level of the soil on account of organic manure mineralization.

Enhanced seeds' attributes in $1,250 \mathrm{~kg} / \mathrm{ha}$ and 2,500 kg/ha application rates over all other treatment was traceable to enhanced rate of decomposition of the applied rice straw (Das et al., 2003). This result was similar that of Muneshwar et al. (2001) regarding the response of wheat on farm yard manure, rice and wheat crop residue.

\section{Proximate composition of groundnut seeds \\ Moisture content}

Moisture content of groundnut seeds before planting was $7.80 \%$ (Table 3). Regardless of the application rates, groundnut raised under unground rice straw retained more moisture compared to ground rice straw.

Plants grown within 5,000 and 3,750 kg/ha ground and unground rice straw application rates recorded significantly the highest moisture content of seeds compared to all other application rates. Ground and unground rice straw applied at the rate of 1,250 and 2,500 $\mathrm{kg} / \mathrm{ha}$ had significantly low moisture content of harvested seeds.

The result was a clear indication that seeds harvested from low rice straw treatment rate will have a longer storage life span. Moisture content has been reported to be of importance in seed storage, because of the correlation between the lower the moisture content of food, the higher the storability (Ajayi and Adedire, 2007).

\section{Ash content}

The ash content of the seeds before planting was 2.29\% (Table 3). Ground and unground rice straw applied at the rate of 2,500 and $1,250 \mathrm{~kg} /$ ha significantly increased the ash content of groundnut seeds compared to all other application rates. Rice straw at 3,750 and $5,000 \mathrm{~kg} / \mathrm{ha}$ application rates had no significant effect on the ash content (Table 3). The increase in ash content of 2,500 and $1,250 \mathrm{~kg} / \mathrm{ha}$ rates could be due to the increase in soil

Table 2. Yield attributes of groundnut

\begin{tabular}{|c|c|c|c|c|c|c|c|}
\hline & $\begin{array}{l}\text { Treatments } \\
(\mathrm{kg} / \mathrm{ha})\end{array}$ & No. of pods/plant & $\begin{array}{c}\text { Pod weight/plant } \\
(\mathrm{g})\end{array}$ & $\begin{array}{l}\text { Pod length } \\
(\mathrm{cm})\end{array}$ & $\begin{array}{c}\text { Number of } \\
\text { seeds per plant }\end{array}$ & $\begin{array}{l}\text { Seeds' weight } \\
\text { per plant (g) }\end{array}$ & $\begin{array}{c}\text { One hundred } \\
\text { seeds' weight (g) }\end{array}$ \\
\hline Ground & $\mathrm{T}_{0}$ & $52.33 \pm 3.48^{b}$ & $36.54 \pm 0.18^{\mathrm{b}}$ & $2.28 \pm 0.04^{\mathrm{a}}$ & $61.00 \pm 0.58^{c}$ & $19.43 \pm 0.57^{b}$ & $33.85 \pm 0.67^{b}$ \\
\hline \multirow[t]{7}{*}{ rice straw } & $\mathrm{T}_{1}$ & $74.33 \pm 0.87^{\mathrm{a}}$ & $41.61 \pm 0.69^{a}$ & $2.27 \pm 0.03^{\mathrm{a}}$ & $77.33 \pm 0.89^{\mathrm{a}}$ & $25.56 \pm 0.31^{\mathrm{a}}$ & $38.05 \pm 0.03^{\mathrm{a}}$ \\
\hline & $\mathrm{T}_{2}$ & $52.67 \pm 0.88^{\mathrm{b}}$ & $42.70 \pm 0.37^{a}$ & $2.29 \pm 0.04^{\mathrm{a}}$ & $67.33 \pm 1.20^{\mathrm{b}}$ & $19.52 \pm 0.70^{\mathrm{b}}$ & $36.86 \pm 1.09^{\mathrm{b}}$ \\
\hline & $\mathrm{T}_{3}$ & $49.00 \pm 0.57^{\mathrm{b}}$ & $33.66 \pm 0.61^{\mathrm{c}}$ & $2.28 \pm 0.03^{\mathrm{a}}$ & $59.66 \pm 0.88^{d}$ & $19.77 \pm 0.12^{\mathrm{b}}$ & $33.39 \pm 1.96^{\mathrm{b}}$ \\
\hline & $\mathrm{T}_{4}$ & $47.33 \pm 3.71^{b}$ & $31.44 \pm 0.15^{d}$ & $2.26 \pm 0.03^{a}$ & $59.66 \pm 1.20^{\mathrm{d}}$ & $17.03 \pm 0.02^{\mathrm{c}}$ & $21.37 \pm 0.5^{c}$ \\
\hline & Total mean & $55.13 \pm 2.76$ & $37.18 \pm 1.18$ & $2.27 \pm 0.01$ & $65.00 \pm 1.85$ & $18.24 \pm 1.37$ & $32.70 \pm 1.61$ \\
\hline & p-value & $<0.001$ & $<0.001$ & 0.953 & $<0.001$ & $<0.001$ & $<0.001$ \\
\hline & $\mathrm{T}_{0}$ & $41.66 \pm 1.20^{c}$ & $21.70 \pm 1.18^{c}$ & $2.27 \pm 0.03^{\mathrm{a}}$ & $44.33 \pm 0.33^{\mathrm{b}}$ & $13.01 \pm 1.46^{\mathrm{b}}$ & $33.78 \pm 0.76^{a}$ \\
\hline Unground & $\mathrm{T}_{1}$ & $48.33 \pm 0.33^{b}$ & $23.95 \pm 0.16^{\mathrm{b}}$ & $2.27 \pm 0.27^{\mathrm{a}}$ & $45.67 \pm 1.20^{\mathrm{b}}$ & $13.15 \pm 0.59^{\mathrm{b}}$ & $34.34 \pm 3.29^{\mathrm{a}}$ \\
\hline \multirow[t]{5}{*}{ rice straw } & $\mathrm{T}_{2}$ & $68.00 \pm 1.00^{\mathrm{a}}$ & $36.43 \pm 0.49^{\mathrm{a}}$ & $2.28 \pm 0.04^{\mathrm{a}}$ & $74.00 \pm 1.02^{\mathrm{a}}$ & $16.40 \pm 0.24^{\mathrm{a}}$ & $35.50 \pm 0.45^{\mathrm{a}}$ \\
\hline & $\mathrm{T}_{3}$ & $44.33 \pm 0.32^{c}$ & $20.99 \pm 1.32^{\mathrm{b}}$ & $2.27 \pm 0.03^{\mathrm{a}}$ & $41.67 \pm 1.20^{c}$ & $12.80 \pm 0.15^{\mathrm{b}}$ & $33.36 \pm 0.87^{\mathrm{a}}$ \\
\hline & $\mathrm{T}_{4}$ & $37.00 \pm 1.00^{\mathrm{d}}$ & $16.62 \pm 3.09^{\mathrm{b}}$ & $2.26 \pm 0.01^{\mathrm{a}}$ & $37.33 \pm 1.45^{\mathrm{d}}$ & $12.78 \pm 0.32^{\mathrm{c}}$ & $27.16 \pm 0.25^{\mathrm{b}}$ \\
\hline & Total mean & $47.86 \pm 2.88$ & $23.94 \pm 1.88$ & $2.27 \pm 0.01$ & $48.60 \pm 3.50$ & $13.14 \pm 0.14$ & $32.83 \pm 0.98$ \\
\hline & p-value & $<0.001$ & 0.005 & 0.997 & $<0.001$ & 0.005 & 0.028 \\
\hline
\end{tabular}

$\mathrm{kg} / \mathrm{ha}, \mathrm{T}_{3}=3,750 \mathrm{~kg} / \mathrm{ha}$ and $\mathrm{T}_{4}=5,000 \mathrm{~kg} / \mathrm{ha}$

Table 3. Pre-planting and postharvest proximate composition of air-dried groundnut seeds

\begin{tabular}{|c|c|c|c|c|c|c|c|}
\hline & $\begin{array}{c}\text { Treatments } \\
(\mathrm{kg} / \mathrm{ha})\end{array}$ & $\begin{array}{c}\text { Moisture content } \\
(\%)\end{array}$ & $\begin{array}{c}\text { Ash content } \\
(\%) \\
\end{array}$ & $\begin{array}{c}\text { Crude fibre } \\
(\%)\end{array}$ & $\begin{array}{c}\text { Crude protein } \\
(\%)\end{array}$ & $\begin{array}{c}\text { Total fat } \\
(\%)\end{array}$ & $\begin{array}{c}\text { Carbohydrate } \\
(\%)\end{array}$ \\
\hline Pre-planting & --- & 7.80 & 2.29 & 3.40 & 30.81 & 46.22 & 8.82 \\
\hline Ground rice & $\mathrm{T}_{0}$ & $10.32 \pm 0.01^{\mathrm{c}}$ & $2.54 \pm 0.01^{\mathrm{b}}$ & $3.34 \pm 0.02^{b}$ & $31.43 \pm 0.05^{\mathrm{b}}$ & $46.65 \pm 0.02^{\mathrm{b}}$ & $5.79 \pm 0.07^{\mathrm{a}}$ \\
\hline \multirow[t]{7}{*}{ straw } & $\mathrm{T}_{1}$ & $10.54 \pm 0.01^{\mathrm{d}}$ & $2.71 \pm 0.04^{\mathrm{a}}$ & $3.22 \pm 0.01^{\mathrm{c}}$ & $31.47 \pm 0.00^{\mathrm{ab}}$ & $46.90 \pm 0.02^{\mathrm{a}}$ & $5.68 \pm 0.05^{\mathrm{a}}$ \\
\hline & $\mathrm{T}_{2}$ & $11.22 \pm 0.03^{\mathrm{e}}$ & $2.73 \pm 0.02^{\mathrm{a}}$ & $3.14 \pm 0.03^{\mathrm{d}}$ & $31.55 \pm 0.03^{\mathrm{a}}$ & $47.13 \pm 0.01^{\mathrm{a}}$ & $5.82 \pm 0.03^{\mathrm{a}}$ \\
\hline & $\mathrm{T}_{3}$ & $10.06 \pm 0.04^{\mathrm{b}}$ & $2.41 \pm 0.02^{\mathrm{c}}$ & $3.35 \pm 0.01^{\mathrm{b}}$ & $31.35 \pm 0.03^{c}$ & $46.57 \pm 0.03^{\mathrm{b}}$ & $5.95 \pm 0.11^{a}$ \\
\hline & $\mathrm{T}_{4}$ & $9.23 \pm 60.04^{\mathrm{a}}$ & $2.34 \pm 0.01^{\mathrm{d}}$ & $3.52 \pm 0.01^{\mathrm{a}}$ & $31.28 \pm 0.00^{\mathrm{d}}$ & $45.91 \pm 0.01^{\mathrm{c}}$ & $6.60 \pm 0.10^{\mathrm{a}}$ \\
\hline & Total Mean & $10.60 \pm 0.16$ & $2.55 \pm 0.04$ & $3.32 \pm 0.03$ & $31.42 \pm 0.02$ & $46.63 \pm 0.16$ & $5.63 \pm 0.05$ \\
\hline & $\mathrm{p}$-value & $<0.001$ & $<0.001$ & $<0.001$ & 0.002 & $<0.001$ & 0.08 \\
\hline & $\mathrm{T}_{0}$ & $10.52 \pm 0.03^{\mathrm{c}}$ & $2.43 \pm 0.01^{\mathrm{b}}$ & $3.33 \pm 0.01^{\mathrm{c}}$ & $31.47 \pm 0.01^{\mathrm{b}}$ & $46.43 \pm 0.02^{\mathrm{b}}$ & $5.85 \pm 0.01^{b}$ \\
\hline Unground & $\mathrm{T}_{1}$ & $11.35 \pm 0.03^{\mathrm{d}}$ & $2.78 \pm 0.01^{\mathrm{a}}$ & $3.05 \pm 0.04^{\mathrm{d}}$ & $31.50 \pm 0.00^{\mathrm{b}}$ & $46.61 \pm 0.02^{\mathrm{a}}$ & $5.94 \pm 0.03^{\mathrm{b}}$ \\
\hline \multirow[t]{5}{*}{ rice straw } & $\mathrm{T}_{2}$ & $10.80 \pm 0.08^{e}$ & $2.79 \pm 0.02^{\mathrm{a}}$ & $2.94 \pm 0.03^{\mathrm{e}}$ & $31.56 \pm 0.01^{\mathrm{a}}$ & $46.65 \pm 0.03^{\mathrm{a}}$ & $6.38 \pm 0.22^{\mathrm{a}}$ \\
\hline & $\mathrm{T}_{3}$ & $10.12 \pm 0.05^{b}$ & $2.37 \pm 0.18^{\mathrm{b}}$ & $3.52 \pm 0.01^{\mathrm{b}}$ & $31.45 \pm 0.00^{\mathrm{b}}$ & $45.62 \pm 0.04^{\mathrm{c}}$ & $5.96 \pm 0.26^{\mathrm{b}}$ \\
\hline & $\mathrm{T}_{4}$ & $10.30 \pm 0.02^{\mathrm{a}}$ & $2.31 \pm 0.02^{\mathrm{b}}$ & $3.79 \pm 0.03^{\mathrm{a}}$ & $31.44 \pm 0.02^{\mathrm{b}}$ & $45.59 \pm 0.16^{c}$ & $5.52 \pm 0.09^{\mathrm{b}}$ \\
\hline & Total Mean & $10.62 \pm 0.14$ & $2.54 \pm 0.06$ & $3.33 \pm 0.08$ & $31.50 \pm 0.02$ & $46.18 \pm 0.22$ & $5.84 \pm 0.01$ \\
\hline & p-value & $<0.001$ & 0.004 & $<0.001$ & $<0.001$ & $<0.001$ & 0.03 \\
\hline
\end{tabular}

Values represent means \pm standard error, $(\mathrm{n}=4)$. Superscript with same letters were not significantly different at $\mathrm{p}<0.05 ; \mathrm{T}_{0}=\mathrm{control}, \mathrm{T}_{1}=1,250 \mathrm{~kg} / \mathrm{ha}, \mathrm{T}_{2}=2,500$ $\mathrm{kg} / \mathrm{ha}, T_{3}=3,750 \mathrm{~kg} / \mathrm{ha}$ and $T_{4}=5,000 \mathrm{~kg} / \mathrm{ha}$ 
potassium, resulting from the mineralization of the straws at optimum concentration, since the major component of ash is potassium (Shaharadeen and Seran, 2013). This result was in agreement with the ash content reported by Atasie et al. (2009) and Olayinka and Etejere (2013) which were $2.4-3.08 \%$ and $2.4-3.10 \%$ respectively.

\section{Crude fibre}

The percentage of crude fibre of groundnut seeds before planting was 3.40\% (Table 3). In both ground and unground rice straw application forms, $5,000 \mathrm{~kg} / \mathrm{h}$ a rice straw application rate significantly increased $(p<0.05)$ the percentage of fibre content. Thus, $3,750 \mathrm{~kg} / \mathrm{ha}$ application rate also followed the same trend, except in ground rice straw, where the increase was insignificant.

The result depicts a correlation between the percentage of moisture content and the crude fibre. The trend noticed in the content of crude fibre may be probably similar to what was adduced for the percentage moisture content of the seeds. The result which ranged between $3.14-3.79 \%$ was at variance with those of Quass (1995), Shahardeen and Seran (2013) or Olayinka and Etejere (2013) who reported a range of 6.00$6.60 \%, 5.95-7.3 \%$ and $7.5-9.12 \%$ respectively.

\section{Crudeprotein}

Crude protein of groundnut seeds before planting was $30.81 \%$ (Table 3). Regardless of the application form, rice straw at $2,500 \mathrm{~kg} / \mathrm{ha}$ application rate significantly increased $(\mathrm{p}<0.05)$ the percentage of crude protein of the harvested seeds. All other application rates had no significant effect on the crude protein (Table 3).

The increase in crude protein may be traced to enhanced availability of potassium for plant use, resulting from the mineralization of rice straw at optimum concentration. Potassium is required for every major step in protein synthesis, therefore increased protein synthesis with increasing potassium availability and uptake by groundnut plant could form the basis for the increase in seed protein content.

Similar results were obtained by Musa et al. (2010) who reported $31.3 \%$ crude proteine, but at variance with Atasie $e t$ al. (2009) who reported $38.61 \%$. The differences could be due to genetic variation in the groundnut seeds.

\section{Crudefat}

The percentage of crude fat of groundnut seeds before planting was $46.88 \%$ (Table 3). Ground and unground rice straw applied at the rate of 1,250 and $2,500 \mathrm{~kg} / \mathrm{ha}$ significantly increased $(p<0.05)$ the crude fat of the harvested seeds compared to all other application rates; however, $3,750 \mathrm{~kg} / \mathrm{ha}$ ground and unground rice straw application rates had no significant effect on the crude fats (Table 3).

The increase in crude fat observed in 1,250 and 2,500 $\mathrm{kg} / \mathrm{ha}$ application rate could be attributed to the low moisture content in the seeds. The result which ranged between $45.59-46.90 \%$ was in agreement with data obtained by Thakur et al. (2005), Atasie et al. (2009), Shawad et al. (2010), Olayinka and Etejere (2013).

\footnotetext{
Total carbohydrate

Total carbohydrate of groundnut seeds before planting
}

was $8.82 \%$ (Table 3). Ground rice straw had no significant effect on seed's total carbohydrate at all application rate considered, with the exception in the case of unground rice straw applied at the rate of $2,500 \mathrm{~kg} / \mathrm{ha}$ which significantly increased the total carbohydrate content of seeds.

The total carbohydrate ranged between $5.52-6.60 \%$, thus being similar with the results obtained by Olayinka and Etejere (2013), who reported a range between 4.99-10.27\%, but at variance with Atasie et al. (2009), who reported 18.1\% for carbohydrate content in groundnut. The variation may be due to varietal differences.

\section{Conclusions}

In conclusion, the forgoing research had shown that lower application rate of both ground and unground rice straw $(1,250$ and $2,500 \mathrm{~kg} / \mathrm{ha})$ positively influenced the yield attributes and some aspects of proximate composition such as ash, crude protein and crude fats for groundnut seeds.

\section{References}

Achou MB, Fokou E, Tciegang C, Fotoso M, Tchouanguep FM (2005). Nutitive value of Cucurbitaceae oil seed from different region in Cameroun. African Journal of Biotechnology 4(11):1329-1334.

Ajayi OE, Adedire CO (2007). Nutrient characteristic of the subterranean termite, Macrotermes subhy (Rambur)(Isoptera: Termitidae). Nigeria Journal of Biotechnology 24:42-47.

Anderson JM, Ingram SJ (1994). Tropical biology and fertility: A Handbook of methods. Soil Science 157(4):265.

AOAC (2000). Official Method of Analysis (17th ed), Volume 1. Association of official Analytical Chemists Inc., Maryland, U.S.A.

Atasie VN, Akinhanmi TF, Ojiodu CC (2009). Proximate analysis and physicochemical properties of groundnut Arachis hypogaeal L.). Pakistan Journal of Nutrition 8(2):194-197.

Basel N, Sami M (2014). Effect of Organic and Inorganic Fertilizers Application on Soil and cucumber (Cucumis sativa L.) Plant Productivity International Journal of Agriculture and Forestry 4(3):166-170.

Binod P, Sindhu R, Singhania RR, Vikram S, Devi L, Nagalakshmi S, Kurien N, Sukumaran RK, Pandey A (2010). Bioethanol production from rice straw: an overview. Bioresource Technology 101(13):4767-4774.

Bremner ET, Mulvan CS (1982). Nitrogen total. Methods of soil analysis, part 2. Chemical and microbiological properties (methodsofsoilan2) pp 595-624.

Das K, Medhi DN, Guha B (2003). Application of crop residue in combination with chemical fertilizers for sustainable productivity in rice (Oryza sativa)-wheat (Triticum aestivum) system. Indian Journal of Agronomy 48(1):8-11.

El-Gammal MI, Shakour AA (2001). Emission of pollutants from harvest and burning of rice straw in Egypt villages (North East of Nile Delta).J Union Arab Biol 15:191-206.

Fageria NK, Baligar VE, Jones C (2010). Growth and mineral nutrition of field crop. CRC Press.

Jana PK, Ghatak S, Barik A, Biswas BC (1990). Response of summer 
180

groundnut to nitrogen and potassium. Indian Journal of Agronomy 35:137-143.

Jones JR, Wolf JB, Mills HA (1991). Preparation and analysis (Chapter 4). In: Plant analysis handbook. A practical sampling, preparation, analysis, and interpretation guide. Micro-Macro Publishing, Athens, Georgia pp 23-26.

Mathivanan S, Kalaikandhan R, Chidambaram AL, Sundramoorthy $P$ (2013). Effect of vermicompost on the growth and nutrient status in groundnut (Arachis hypogaea. L). Asian Journal of Plant Science and Research 3(2):15-22.

Muneshwar SI, Singh VIP, Sunni Reddy K (2001). Effect of integrated of N. K. and $S$ and productivity of rice-whed system on vertisol. Journal of Indian Society of Soil Science 49(3):430-435.

Musa AK, Kalejaiye DM, Ismail LE, Oyerinde AA (2010). Proximate composition of selected groundnut varieties and their susceptibility to Trogoderma granarium Everts attack. Journal of Stored Products and Postharvest Researh 1(2):13-21.

Nelson DW, Somners LE (1982). Total carbon, organic carbon and organic matter. In: Page AL (Ed). Methods of soil analysis: Part 2, Agron Monogr 9, 2nd ed. ASSA and SSSA, Madison, WI pp 539-594.

Obi ME, Ebo PO (1995).The effect of different management practices on the soil physical properties and maize production in severely degraded soil in Southern Nigeria. Biological Resource Technology 51:117-123.

OkaleboJR, Gathua KW, Woomer PL (2002). Laboratory methods of soil and plant analysis (2nd ed) Nairobi, Kenya.
Olayinka BU, Etejere EO (2013). Influence of weed management strategies on proximate composition of two varieties of groundnut (Arachis hypogaea L.). Annals. Food Science and Technology $14(2): 286-293$.

Quass CF (1995). Guidelines for the production of cowpeas. National Department of Agriculture, Pretoria. South Africa pp 1-17.

Savage GP, Keenan JI (1994). The composition and nutritive value of groundnut Kernels. In Smart J (Ed). The groundnut crop: Scientific basic of improvement. London: Chapman and Hall pp 173-213.

Shahardeen RNM, Seran TH (2013). Impact of animal manure EMbokashi on seed yield and quality of vegetable cowpea (Vigna unguiculata L.). Bangladesh Journal of Scientific and Industrial Research 48(1)33-38.

Shawad UK, Agasinmani CA, Aravndkumar BN, Shuvamurth SD, Ashork S, Jalageri BR (2010). Integrated weed management (IWM): A long time case study in groundnut wheat cropping system in Northern Kornataka. Research Journal of Agricultural Science 1(3):196-200.

Thakur S, Shrivastava SK, Shrivastava M (2005).Toxic factors in some new varieties of oil seeds. International Journal of Chemistry Science 3(4):695-698.

Veluchamy B, Krishnamoorthy V, Kolundu S, Anbazhagan I, Konganapuram CR (2010). Application of organic halophytic manure on yield characteristics of Arachis bypogaea (L).. International Journal of Engineering, Science and Technology 2(1):134-143. 